\title{
Comparative Analysis of Competitiveness of Logistics Companies in Korea, Japan and China
}

\author{
JunYeop Lee*, Myunghun Lee**
}

\begin{abstract}
This paper examines the comparative corporate performance of logistics companies in Korea, China and Japan. Based on the annual data from the listed companies, the growth rate of Chinese companies has surpassed that of Korean and Japanese companies and has labeled China as the fastest growing economy. How ever, labor efficiency of Chinese firms when calculated by total revenue per employee is the lowest of the three countries. In addition, the profitability of Chinese multimodal logistics companies and sea transport companies is also lower than that of Korea and Japan.

Using Data Envelop Analysis(DEA), the primary results regarding corporate efficiency among Korean, Chinese and Japanese logistic companies are as follows: In the multimodal industries, Japanese firms have revealed the highest level of efficiency, with Korean firms coming in second, and Chinese firms ranking third with distinctly inferior performance. This trend has also been examined in the maritime industries, in which the efficiency levels have been deteriorating continuously. However, in the air transportation industry Chinese companies revealed the highest level of efficiency, which resulted from the business characteristics of the government supported conglomerate companies.
\end{abstract}

Keywords: logistics companies, corporate performance, DEA, Korea, Japan and China

Submission Date: 5/16/2011 Revision Date: 05/20/2011 Acceptance Date: 05/20/2011

* Corresponding Author : Professor, School of International Trade and Regional Studies, Inha University, Korea, Tel: + 8232860 7804, Email: jylee@inha.ac.kr

${ }^{* *}$ Professor, School of International Trade and Regional Studies, Inha University, Korea, Tel: + 8232860 7805, Email: leemh@inha.ac.kr 


\section{Introduction}

For individual logistics companies, what are the consequences of rapid economic growth, accompanied by a surge in commercial transportation traffic in Northeast Asia? Corporate business efficiency and the performance of individual firms are closely related to overall sound growth in the logistics industry.

It is generally accepted that there is a positive correlation between economic growth and growth with in the logistics industry in specific regions(Kessides, 1996; Fritsch and Prud'homme 1997; Tongzon and Nguyen, 2009; Nguyen and Tongzon, 2009). A well-equipped logistics infrastructure also has a positive impact on foreign corporate investment(Hong, 2007). It is natural that in the fast growing Northeast Asian region that the logistics industry seems to keep pace with economic growth.

However, the success of individual firms' is not guaranteed by the overall growth of the industry it self. Expansion in an industry cannot support corporate success directly, as in the case of the U.K. and Taiwanese 3PL firms. Excellence in operations is more important for financial performance than a wide-range of services(Liu and Lyons, 2011).

The growth of the logistics industry in Northeast Asia is mainly due to the rapid growth of China's logistics industry. The increase in logistics in the region has been mainly due to China's huge increase of logistical demand. As for China, the total freight quantity has increased from 14.02 billion tons in 2001 to 28.25 billion tons in 2009, while Korea's total freight has increased from 1.36 billion tons to 2.83 billion tons. It is very striking that Japan's freight decreased from 6.37 billion tons to 4.83 tons from 2001 to 2009.

As China grows at a rapid pace, economic integration in Northeast Asia is intensified by the means of an international division of labor in this area. Considering that logistical services have the marketing structure of both international networking and international competition, Korean and Japanese firms' corporate successes will be influenced by the business competitiveness of Chinese firms and vice versa.

Even though China's business environment has improved due to economic reforms and globalization, when compared to Korea and Japan, there are many distinctive factors which influence the individual firms' business in each country. In China, the large state-owned enterprises have a dominant status in air transportation, maritime transportation and in logistical infrastructure management. The domestic market was gradually opened after China's entry into the WTO, yet foreign companies are still struggling to compete in China's domestic market. However, in Korea and Japan, several large group companies have an oligopolistic market status.

In this paper, we will focus on the performance of individual corporations and the comparative competitiveness of the logistics industry will also be examined. In Section 2, 
the general growth pattern of the logistics industry will be described. In Section 3, the descriptive features of corporate business performance will be examined. In Section 4, we will use Data Envelop Analysis in order to evaluate comparative corporate efficiency. In section 5, we will evaluate policy trends and describe the possible implications that can be drawn for Korea and other countries. In the final section, we will summarize our main arguments and make recommendations which could help benefit the industry.

\section{Growth of Logistical Industries and Companies}

Since 2001, the logistics quantity in Northeast Asia has increased very rapidly due to China's expanding economy. It is an interesting fact that China's logistical quantity has doubled, while Korea has shown little growth and Japan's logistical growth has been on the decline for the past decade (Figure 1). China's growth in logistical quantity has created a large gap between China and its counterparts, making China's logistics market the largest in Northeast Asia.

The rapid increase in China's logistics market and the comparably stagnant trends in the Korean and Japanese logistics industries can be verified by the current popularity in container shipping (Figure 2). In 2000, container port traffic in China, Korea and Japan was respectively 41.0, 9.03 and 13.1 million TEUs. However, in 2009, container traffic had increased to $105.98,16.05$ and 16.29 million TEUs.

One interesting phenomenon about logistics traffic in China is that, in comparison to the amount of international trade, their logistics quantity is extremely large(Figure 3). In 2000 , China's total amount of international trade was $\$ 474.4$ billion, while Japan's was $\$ 858.2$ billion. This means that Japan's trade amount was roughly 1.81 times greater than China's. However, the container traffic volume in China was 3.13 times greater than Japan's. In 2009, China's trade amount was \$2,207.3 billion dollars which surpassed Japan's $\$ 1,133.5$ billion. China's trade amount was 1.95 times larger than Japan's, but China's container traffic was 6.5 times larger than Japan's. Also from 2001 to 2009, the ratio of China's logistics quantity to trade amount increased continuously(Figure 3). The comparatively higher growth rate in China's logistics industry can also be observed by its growth with regards to adding value to the industry. China's growth rate has helped increase value added activities in the logistics industry and has allowed it to surpass both Korea and Japan.

With the exception of the 2009 global crisis, Korea and Japan have maintained astable ratio of added value in their GDP's. It is very interesting that even though China's logistical quantity has increased dramatically, its value added ratio to GDP has continuously decreased. This phenomenon could imply that China has strong competition and its industry 
has stayed a low value added industry which has hindered them from contributing added value totheir GDP.

(unit:billion tons)

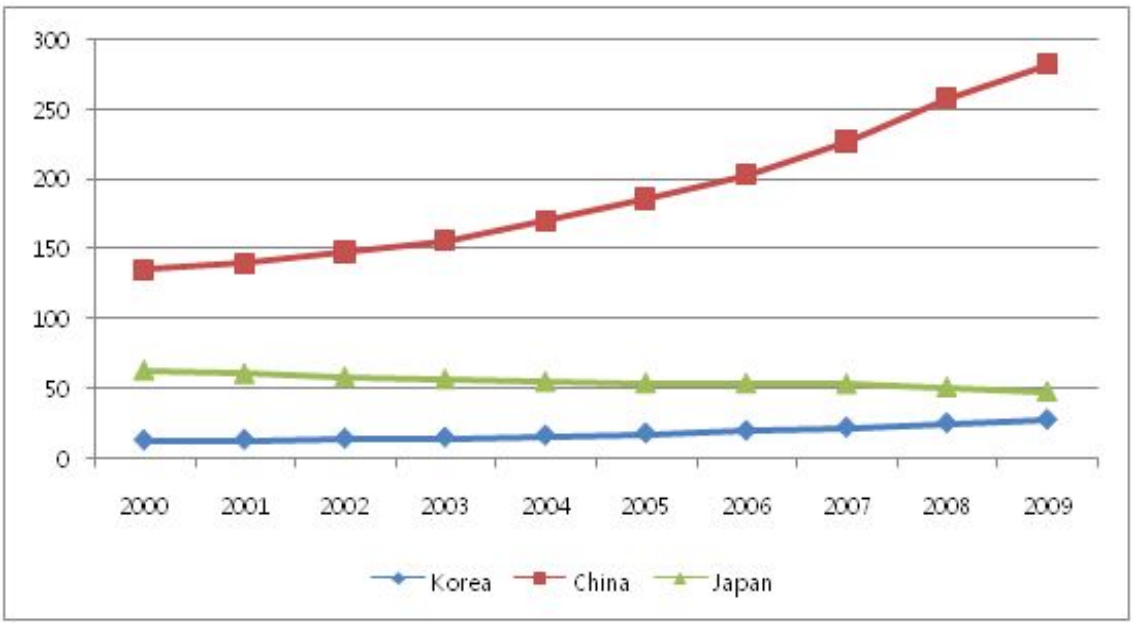

Source: World Bank WDI

Figure 1.

Total Logistics Quantity in Korea, China and Japan

(unit: 1 TEU)

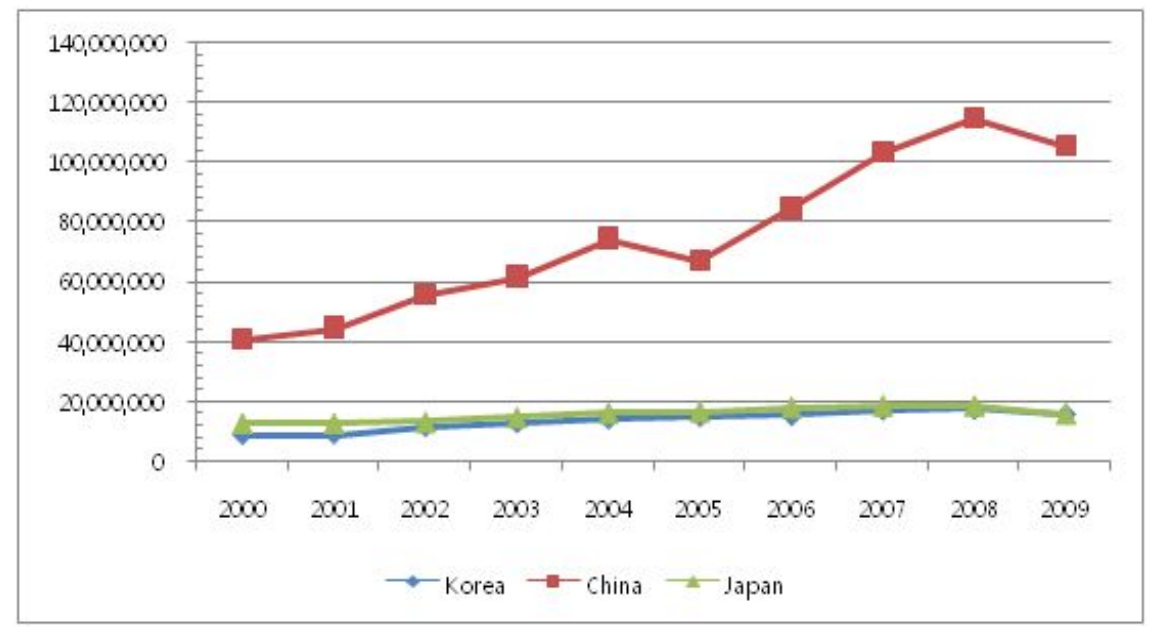

Source: World Bank WDI

\section{Figure 2.}

Container Quantity 


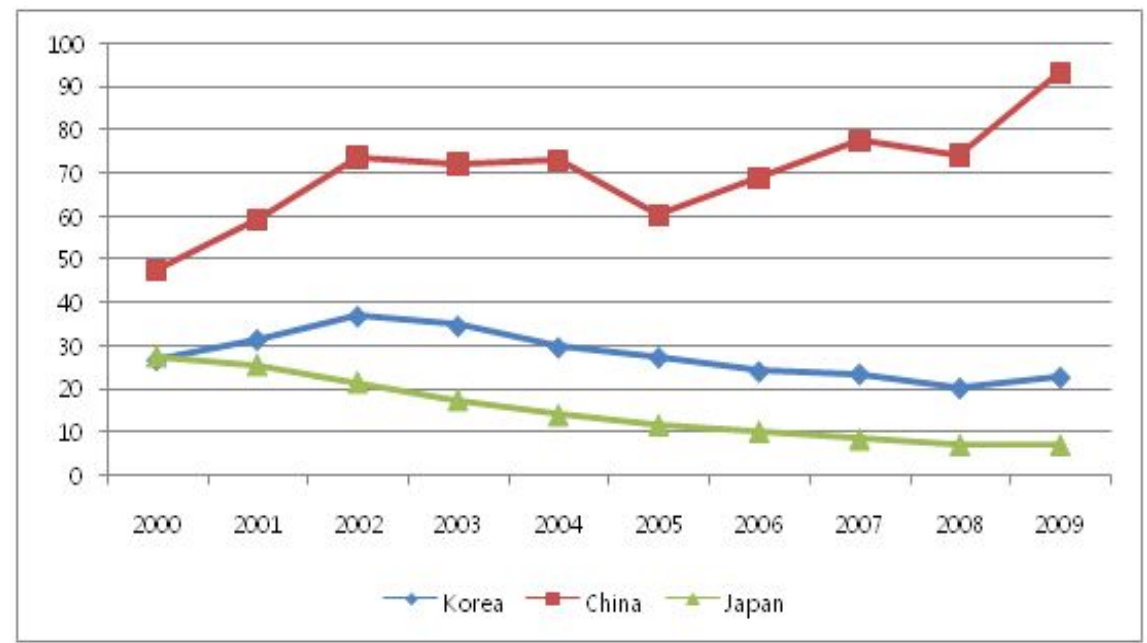

Source: World Bank WDI, Korea International Trade Association(KITA)

Figure 3.

Ratio of Container Traffic in Foreign Trade Volume

Note: Ratios are calculated by container traffic quantity.(TEU) is divided by total International trade(million U.S. dollars).

$(\%)$

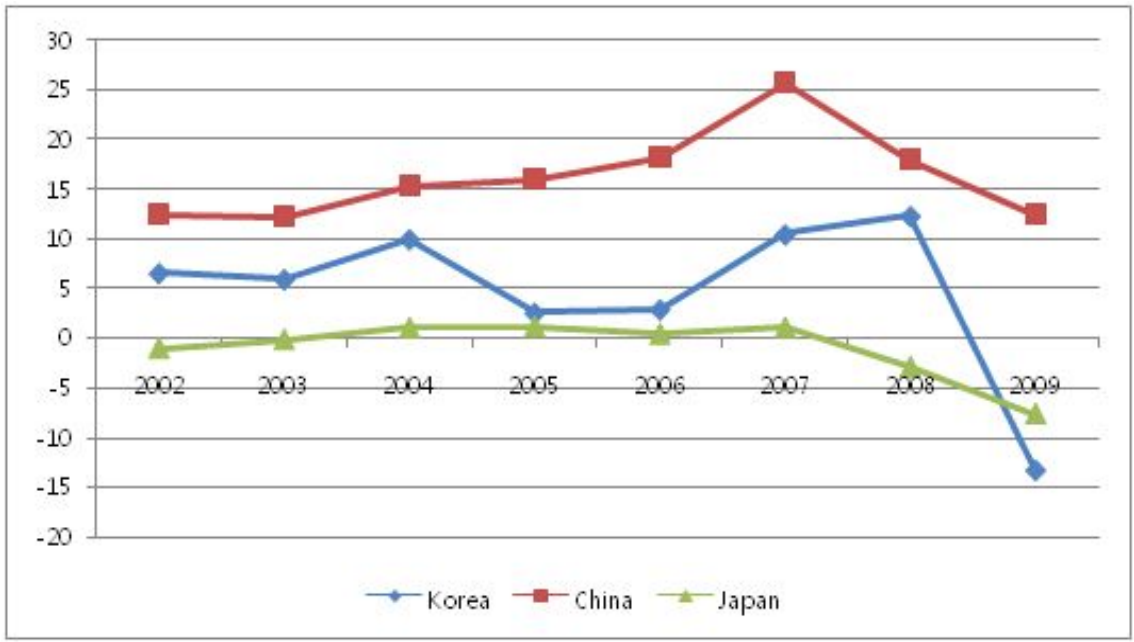

Source: World Bank WDI

Figure4.

Growth rate of the value added logistics industry 
$(\%)$

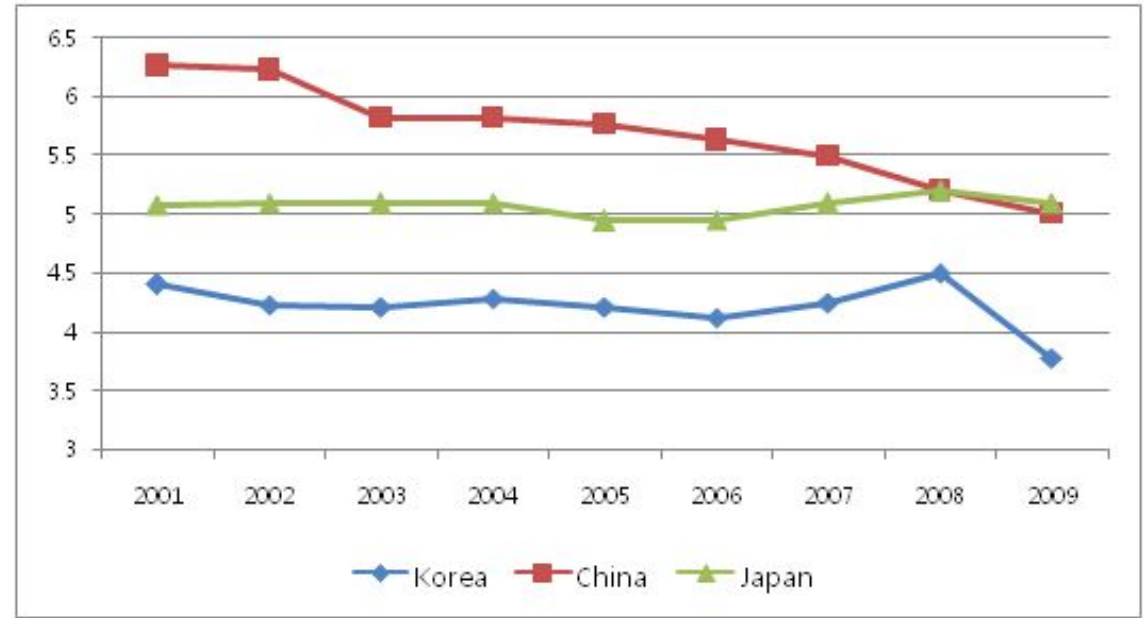

Source: World Bank WDI

Figure5.

Portion of logistics value added to GDP

\section{Comparative Productivity of Logistics Companies in Korea, Japan and}

\section{China}

\subsection{Data and Methodology}

In order to examine corporate performance between China, Korea and Japan, comparative managerial efficiencies must be calculated using Data Envelop Analysis. Data was obtained from logistics companies which were listed on the stock exchange from 2004 to 2009.The companies used for our analysis are listed in table 1. In order to take the different business characteristics into account, the companies are classified into three different types: multimodal transport companies, maritime transport companies and air transport companies.

DEA is a non-parametric technique which is used to measure comparable efficiency of firms in the same industry. It calculates an efficiency score which has a value from 0 to 1. For the input-based DEA, an efficiency score of $1(100 \%)$ means that the firm has the highest level of efficiency compared to other firms' input-output scopes. The firm is producing products or services in the most efficient way in the sense that it cannot decrease 
input without decreasing additional output. An efficiency score below $1(100 \%)$ means that the firm is producing products or services in an inefficient way. DEA methodology has two different models; The CCR model ${ }^{1}$ ) assumes constant returns of scale production functions and the $\mathrm{BCC}$ model2) allows variable returns of scale production functions which calculate pure technical efficiency.

In this DEA model, corporate revenue is assumed to be an output factor and total capital and labor costs are the two input factors. All variables are denominated in the same currency value, U.S. dollars. The BCC-based efficiency scores are presented because there are not any meaningful differences in the business efficiency trends between the efficiency scores of the BCC and the CCR models.

\section{Table 1.}

List of companies

\begin{tabular}{|c|c|c|}
\hline \multirow{3}{*}{$\begin{array}{l}\text { Multimodal } \\
\text { transport }\end{array}$} & Korea & $\begin{array}{l}\text { KOR Exp, Dongbang TRNSPT \& L, Sebang, KCTC, Hansol } \\
\text { CSN, Hanjin TRNSPT }\end{array}$ \\
\hline & Japan & $\begin{array}{l}\text { Mitsubishi Logistics, MITSUI-SOKO, Yamatane Co., Japan } \\
\text { Transcity, ASAGAMI Co., THE KEIHIN Co., RINKO Co., } \\
\text { MEIKO TRANS, Utoc Co., ISEWAN TERMINAL SERVICE, } \\
\text { SUZUYO SHINWART, FUSHIKI KAIRIKU UNSO, TRADIA, } \\
\text { KIMURA UNITY, K.R.S., Yusen Air \& Sea Service, Kintetsu } \\
\text { World Express, Azuma Shipping. }\end{array}$ \\
\hline & China & $\begin{array}{l}\text { SINOTRANS, ShanghaiInt'l Port (Group) Co., Tianjin Port Co., } \\
\text { GuangdongNanYue Logistics Co., Shanghai Jiao Yun Co., } \\
\text { Xiamen Int'l Port Co., Dazhong Transportation (Group) Co }\end{array}$ \\
\hline \multirow{3}{*}{$\begin{array}{l}\text { Maritime } \\
\text { transport }\end{array}$} & Korea & $\begin{array}{l}\text { STX Pan Ocean, KOR LINE, HYUNDAI MERC MAR, } \\
\text { HEUNG-A SHIPPING }\end{array}$ \\
\hline & Japan & $\begin{array}{l}\text { Nippon Yusen Kabushiki Kaisha, Mitsui O.S.K. Lines, Ltd., } \\
\text { Kawasaki Kisen Kaisha, Ltd. }\end{array}$ \\
\hline & China & $\begin{array}{l}\text { COSCO Shipping Co., Nanjing Tanker Co., Chang Jiang Shipping } \\
\text { GroupPhoenix Co., Tianjin Maritime Shipping Co.. }\end{array}$ \\
\hline \multirow{3}{*}{ Air transport } & Korea & KAL, Asiana Airlines \\
\hline & Japan & $\begin{array}{l}\text { ANA, Skymark Airlines Inc., PASCO, Asia Air Survey Co., } \\
\text { Ltd. }\end{array}$ \\
\hline & China & $\begin{array}{l}\text { China Southern Airlines, Air China, China Eastern Airlines, } \\
\text { Hainan Airlines, Shandong Airlines }\end{array}$ \\
\hline
\end{tabular}

Source: stock exchanges in Korea, Japan and China

1) Charnes, A., Cooper, W.W, and Rhodes, E.L., 1978, "Measuring the efficiency of decision-making units," European Journal of Operation Research, 2, 429-444.

2) Banker, R.D., Charnes, A., and Cooper, W.W. ,1984, Some models for estimating technical and scale in efficiences in data envelop analysis, Management Science, 30, 1078-1092. 


\subsection{Descriptive trends of logistics companies}

A country's outstanding economic growth helps support the subsequent growth of the logistics industry. However, can the overall growth pattern of logistics industries guarantee superior corporate performance for individual companies?

Before presenting detailed analysis, the distinctive business trends of the listed logistics companies in Korea, China and Japan are described. Firstly, the strikingly high growth rate of China's logistics industry can be observed by the much higher growth rate of the individual firms' corporate revenues.

Secondly, the profitability ratio of Japanese and Korean companies has been much higher than that of Chinese firms in the multimodal and sea transport industries. However, for air transportation companies, Chinese firms have revealed the highest level of profitability. The monopolistic power of Chinese air transport companies and their state-owned governance have had a positive influence on their profitability, especially given the fact that Korean and Japanese air transport companies have struggled due to shrinking demand for their services during the global crises.

Thirdly, labor productivity, which is measured by revenue per employee, shows that Japanese logistic firms have the highest level of business efficiency in the areas of multimodal logistics and sea transportation with Korean firms claiming the highest level of labor productivity in air transportation. The low levels of labor productivity in all industrial areas in China shows that Chinese firms have lax management in relation to an abundant amount of labor. However, Chinese firms are being forced to improve their levels of labor efficiency largely due to the current trend in increasing wages which began recently.

Table 2.

Descriptive corporate performance in 2004-2009

\begin{tabular}{c|c|c|c|c|c|c|c|c|c}
\hline & \multicolumn{3}{|c|}{$\begin{array}{c}\text { Growth rate of } \\
\text { Revenue } \\
(\%)\end{array}$} & \multicolumn{3}{c|}{$\begin{array}{c}\text { Revenue per } \\
\text { employee } \\
(10,000 \text { U.S. \$) }\end{array}$} & \multicolumn{4}{c}{ ROA(\%) } \\
\hline \hline & Multi & Sea & Air & Multi & Sea & Air & Multi & Sea & Air \\
\hline Korea & 5.9 & 9.2 & 4.1 & 43.5 & 248.2 & 48.2 & 2.1 & 5.7 & 0.08 \\
\hline China & 53.8 & 13.6 & 18.6 & 12.7 & 40.7 & 17.0 & 0.1 & 3.2 & 0.59 \\
\hline Japan & 1.2 & 5.9 & 11.8 & 74.9 & 800.1 & 41.9 & 1.9 & 6.5 & -1.47 \\
\hline
\end{tabular}

Note: All numbers are average values during the years 2004-2009. 


\subsection{Business Efficiency in logistical companies}

From the DEA efficiency analysis of Korean, Chinese and Japanese logistics firms, two noticeable characteristics can be identified. The first one is the inferior level of efficiency in the Chinese firms and the second is the deteriorating rate of efficiency in Chinese firms after 2008.

For multimodal logistics companies and maritime transportation companies, Japanese firms have the highest efficiency score while Korean firms show the second highest efficiency rating. Comparatively, Chinese firms reveal the poorest efficiency scores in these areas(Figure 6, Figure 7).

In the air transportation industry between 2005-2007 Chinese companies had the highest level of efficiency, but after the global financial crisis struck in 2008 their efficiency scores were overtaken by both Korean and Japanese firms(Figure 8). Chinese firms have also recently shown deteriorating levels of efficiency in the multimodal and maritime transportation industry.

There are two reasonable explanations for the recent trend in decreased efficiency in Chinese firms. One explanation is based on a market factor while the other results from an owner ship factor. As seen in the descriptive corporate performance graph from 2004-2009, China's logistics market has distinct differences when compared to Korea'sand Japan's. China's logistics market has grown remarkably fast, but labor efficiency and financial performance (except in the Air transportation industry) are inferior to that of the Korean and Japanese firms. This may imply that the excessive investment by the individual firms in the expanding market might cause lower levels of efficiency.

The other possible answer could be the distinctive type of ownership which is found in Chinese firms. With the exception of Dazhong Transportation, listed in table 1, all of the Chinese companies are state-owned enterprises. This would indicate that Chinese logistics firms have been negatively influenced by state-ownership(Holz,2002; Qi et al., 2000). Zhang et al.(2001)analyzed 1,838 companies located in Shanghai between 1996 to 1998, and argued that non-SOEs have a higher level of productivity than SOEs and that the type of ownership is a more important factor in determining the level of efficiency in a company than other factors, such as intra-industry competition. The productivity and efficiency levels of Chinese state-owned enterprises, in comparison with the private-owned companies in Japan and Korea are markedly low and ownership may be a contributing factor. 
Table 3.

Average DEA efficiency score

$(\%)$

\begin{tabular}{c|c|c|c|c|c|c}
\hline \multicolumn{7}{c}{ Multimodal Logistics } \\
$\begin{array}{c}\text { Country } \\
\text { Year }\end{array}$ & 2004 & 2005 & 2006 & 2007 & 2008 & 2009 \\
\hline Korea & - & 44.9 & 47.2 & 51.1 & 50.7 & 54.6 \\
\hline China & - & 33.5 & 24.3 & 35.8 & 33.5 & 28.7 \\
\hline Japan & - & 57.1 & 49.1 & 60.4 & 58.6 & 57.5 \\
\hline \multicolumn{7}{|c|}{ Air Transportation } \\
\hline $\begin{array}{c}\text { Country } \\
\text { /Year }\end{array}$ & 2004 & 2005 & 2006 & 2007 & 2008 & 2009 \\
\hline Korea & - & 85.6 & 76.8 & 72.9 & 90.7 & 87.8 \\
\hline China & - & 89.8 & 84.6 & 90.2 & 83.6 & 84.5 \\
\hline Japan & - & 82.3 & 79.6 & 75.1 & 78.9 & 85.9 \\
\hline \multicolumn{7}{c}{ Maritime Transportation } \\
\hline $\begin{array}{c}\text { Country } \\
\text { YYear }\end{array}$ & 2004 & 2005 & 2006 & 2007 & 2008 & 2009 \\
\hline Korea & 93.7 & 79.1 & 74.0 & 77.5 & 82.2 & 85.5 \\
\hline China & 53.8 & 62.0 & 40.1 & 34.5 & 31.3 & 30.5 \\
\hline Japan & 77.5 & 87.6 & 88.6 & 87.2 & 85.2 & 89.5 \\
\hline
\end{tabular}

Note: SINOTRANS, Air China in the year 2005 and STX Pan Ocean in the years 2004, 2005were excluded during the calculation of DEA efficiency due to a lack of data.

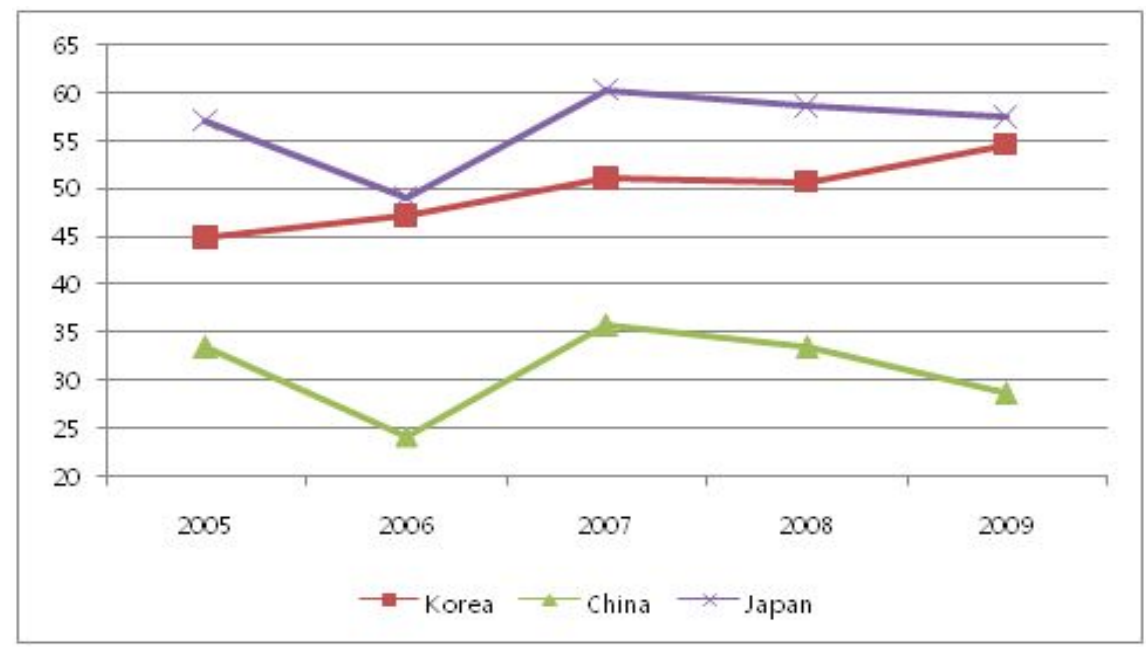

Figure 6.

DEA efficiency scores of Multimodal Logistics companies 


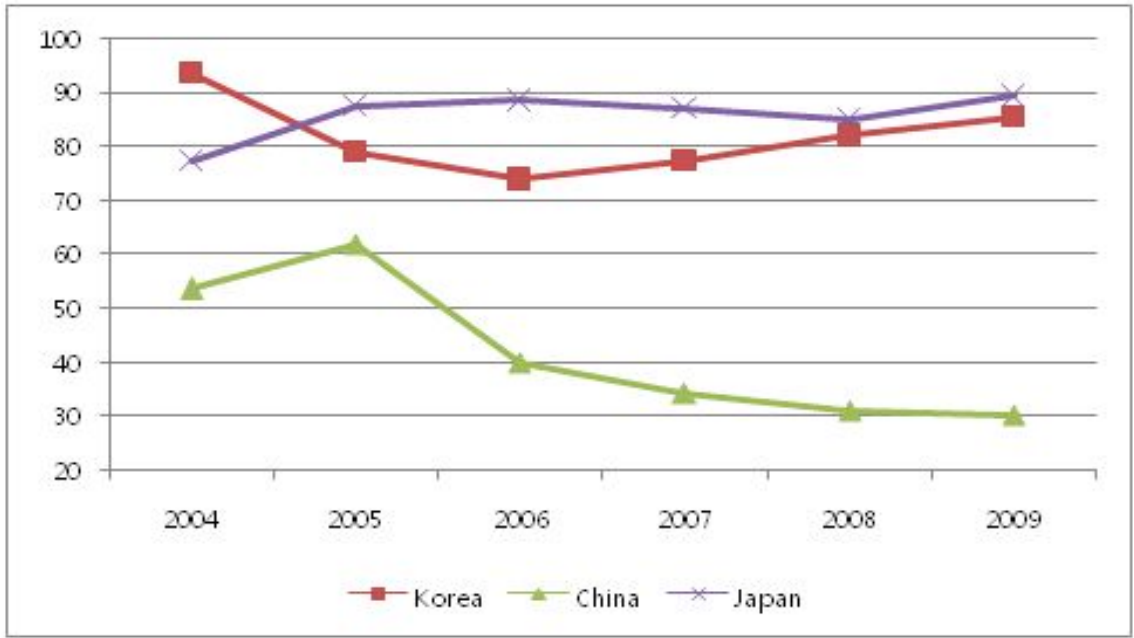

Figure 7.

DEA efficiency scores of Maritime Transportation companies

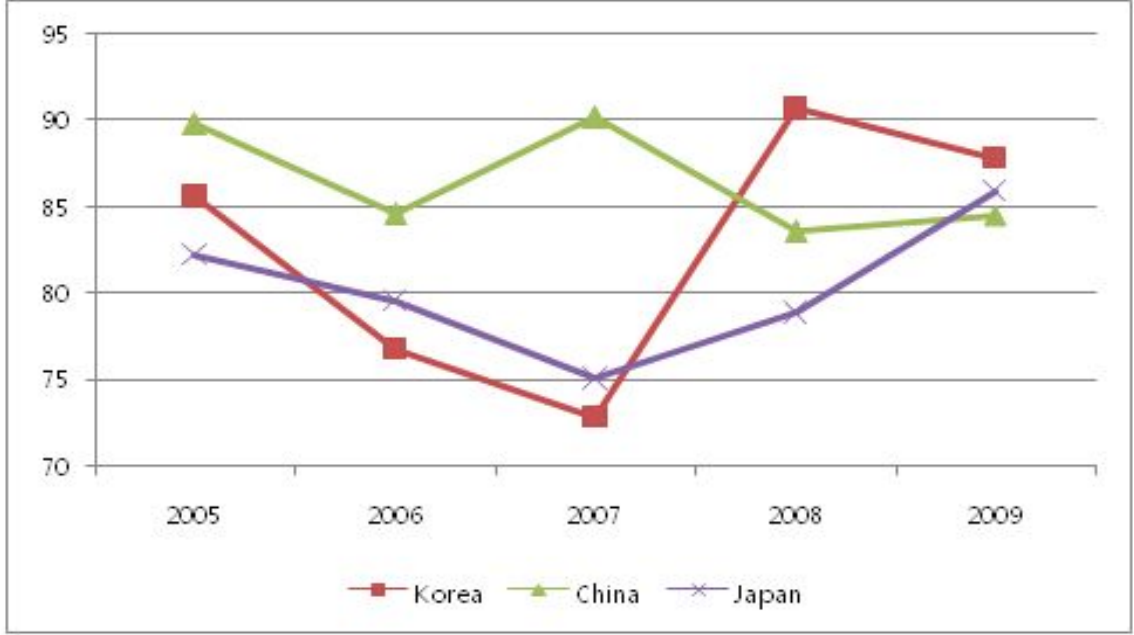

Figure 8.

DEA efficiency scores of Air Transportation companies

\section{Policy Implications}

Based on the DEA efficiency evaluation, Japanese and Korean logistics companies surpassed Chinese companies in their level of operating efficiency. These results are 
interesting in the sense that deteriorating business efficiency coincides with the fast growing logistics market. The larger logistics firms in China are mainly composed of state-owned enterprises whose style of ownership might require a stronger policydependant environment than the logistics firms in Korea and Japan.

The origin and development of Chinese logistics firms was closely related to Chinese corporate reforms. SOE reform measures have proposed ideas since the mid 1990s such as 'retaining the larger, and letting the smaller (juadafangxiao),' and' corporatization (gongsihua),' has had a critical impact on the for mation of conglomerate logistics firms.

Since the mid 1990's, SOE's policy measures have largely focused on reforming corporate governance and resolving the SOEs' low levels of profitability. 'Retaining the larger and letting the smaller' was introduced to create measures to help un profitable SOEs in 1996. From this policy, the core and large SOE companies were reorganized into conglomerate firms, while the 'asset optimization plan' and 'corporatization' plans were introduced to enhance the competitiveness and transparency of newly restructured conglomerate companies.

Based on these guidelines, many new logistics conglomerates were established. For example, China Ocean Shipping (Group) Company(COSCO), China's largest logistics company, whose fleet size ranks second in the world and ranks 327 on the Fortunes 500list, was restructured and rebuilt in 1993. COSCO now owns six companies listed respectively in Shanghai, Singapore and Hong Kong and has 544 subsidiary firms. SINOTRANS the largest 3PL company was established in 1950 and reorganized in 2002. SINOTRANS was listed in Hong Kong in 2003 and owns 3 listed companies with 1200 subsidiaries.

In the field of air transportation, Air China saw changes in management due to the 10th Five-Year Plan, which separated the administration of SOE's from the government and decentralized airport management to local authorities from the Civil Aviation Administration in China. Through this policy, Air China, which used to be one business unit of CAAC, was separated and rebuilt. At the same time 6 other companies under CAAC were also separated and rebuilt. Those companies included China National Aviation Holding Company, China Eastern Air Holding Company, China Southern Airlines Co., Ltd., China Travel Sky Holding Company, China National Aviation Fuel Holding Company, and China Aviation Supplies Holding Company.

Interestingly, all of these newly rebuilt logistics companies are owned by the central government, that is to say, the ultimate shareholder in these companies is the SASAC (State-owned Asset Supervision and Administration Commission of the State Council). This ownership type implies that there exists possibilities for profit manipulation and business appropriations by the controlling shareholders(Jian and Wong, 2006). It was only after 2009 that a national level plan for the logistics industry was proposed. Prior to 2009, 
the main reconstruction policy was the SOE reform measures which were critical factors in determining the level of individual logistics firms' business performance.

As a result of the policy-driven restructuring of these logistics companies, Chinese firms are generally larger than logistics firms in other countries. In the area of sea transportation, the asset size of COSCO in 2009 was $\$ 19,856.4$ million U.S., while that of HYUNDAI MERC MAR was \$3,535.0 million and Nippon Yusen Kabushiki Kaisha was \$15052.51 million.

In contrast to China's delayed policy regarding logistics companies, Korea and Japan have introduced more detailed and up-to-date policies. In Korea, the 'Fundamental National Plan for Logistics, 2nd amendment' was proposed in 2006. In 2007, the 'Basic Law for Logistics Policy' was enacted. Since 2006, the most significant policy thus far, the, Certification System for Integrated Logistics Company",was introduced mainly to support the3PL companies.

In Japan, logistics industry policy is more comprehensive. In 2001, the 'Comprehensive Program of Logistics Policies' was proposed, in which the main goal was to promote competitiveness of logistics companies by promoting integrated logistics, 3PL outsourcing and IT-based logistics such as electronic data interchange, the intelligent transport system and the geographic information system. In 2009, the 'New Comprehensive Program of Logistics Policies' was announced. The main policies contained advanced ideas such as constructing a seamless global logistics scheme, seeking green logistics and enhancing logistics security.

In China, since the SOE restructuring, the most important policy for the logistic industry has focused on improving the logistics infrastructure. Mega projects such as the construction of seaports, airports and railroads have been successfully completed. These policies have enabled China's logistics hardware to be competitive with that found in other countries. Wu and Goh (2010) even argued that China's container ports are currently in the most efficient group while Japan and Korea's ports are in the second most efficient group. These changes have also enabled the introduction of foreign logistics companies into China. In the Chinese market, the transportation infrastructure is one of the determining factors for the location of foreign logistics firms (Hong, 2007). 


\section{Concluding Remarks}

The business performance of Chinese logistics firms could be assessed as being inferior to that of Korean and Japanese firms. With their fast growing logistics industry, the Chinese firms have seemed to pursue corporate size expansion, while Korean and Japanese firms have sought operating efficiency.

However, because of China's economic growth, the Chinese logistics market could still become the dominant market in Asia since this in turn will enhance the overall competitiveness of Chinese companies.

In addition, the state ownership of these companies is a vulnerable factor for the Chinese firms, and is something which should be addressed in the near future. Several factors are reasonable answers for their lack of efficiency progress. One is that their larger corporate size will reveal economies of scale in this fast growing market. The second reason relates to the current trend in globalization. Many conglomerate logistics firms are currently operating in foreign markets. The characteristics of global networking in the logistics industry could enhance the level of globalization for the Chinese companies. In addition, China will attain a higher level of globalization as more foreign companies open up businesses in China.

Steinfeld (2010) argues that Chinese firms will have to conform to global standards as they enter the global market. By entering into the global market, the vulnerabilities of Chinese firms, which are largely due to traditional systems, will diminish. Korea's corporate

policy has prepared it to embrace future opportunities with in China by actively integrating it self into the logistics value chain in northeast Asia. 


\section{Acknowledgements}

This work was supported by the Korea Research Foundation Grant by the Korean government(KRF-2008-005-J01602).

\section{References}

Banker, R.D., Charnes, A., and Cooper, W.W. , 1984, Some models for estimating technical and scale inefficiences in data envelop analysis, Management Science, 30, 1078 $-1092$.

Charnes, A., Cooper, W.W, and Rhodes, E.L., 1978, Measuring the efficiency of decision-making units, European Journal of Operation Research, 2, 429-444.

Cullinane, Kevin, 2004, The container shipping industry and the impact of China's accession to the WTO, Research in Transportation Economics, vol.12, pp. 221 -245 .

Fritsch, B., and Prud 'homme, R., 197, Measuring the contribution of local infrastructure to economic development in France, In: Quinet, E., Vickerman, R. (Eds.) The econometrics of major transport infrastructure. Macmillan, London.

Holz, Carsten A., Long live China's state - owned enterprises: deflating the myth of poor financial performance, Journal of Asian Economics, Vol.13,2002,pp.493-529.

Hong, Junjie, 2007, Transport and the location of foreign logistics firms: The Chinese experience, Transportation Research Part A,vol.41,pp.597-609.

Jian, M., and T. J. Wong, Earnings Management and Tunneling through Related Party Transactions: Evidence from Chinese Corporate Groups, Working Paper,2006.

Kessides, C., 1996, A review of infrastructure's impact on economic development, In: Batten, D., Karlsson, C. (Eds.), Infrastructure and the complexity of economic Development, Chapter12,pp.213-230.

Liu, Chiung-Lin and Andrew C. Lyons, 2011, An Analysis of third-party logistics performance and service provision, Transportation Research Part E, vol.47, pp.547-570.

Liu, Wei Min and Maria K.R. Luk, 2009, Reform and opening up: Way to the sustainable and harmonious development of air transport in China, Transport policy, vol.16, pp.215-223.

Nguyen , Hong-Oanh and Jose Tongzon, 2010, Causal nexus between the transport and logistics sector and trade: The case of Australian case, Transport policy, vol.17, pp.135-146. 
Panayides, Photis, M., Neophytos Lambertides and Christos S. Savva, 2011, The Relative efficiency of shipping companies, Transportation Research Part E, vol.47, pp.681-694.

Qi, Daqing, Woody Wu, and Hua Zhang, Shareholding structure and corporate performance of partially privatized firms: Evidence from listed Chinese companies, PacificBasin Finance Journal, Vol. 8, 2000, pp. 587-610.

Tongzon, Jose and Hong-Oanh(Owen) Nguyen, 2009, China's economic rise and its implication for logistics: The Australian case, Transport policy, vol.16, pp.224 -231 .

$\mathrm{Wu}$, Yen-Chun Jim and Mark Goh, 2010, Container port efficiency in emerging and more advanced markets, Transportation Research Part E, vol.46, pp.1030-1042.

Charnes, A., Cooper, W.W, and Rhodes, E.L., 1978, Measuring the efficiency of decisionmaking units, European Journal of Operation Research, 2, 429-444.

Banker, R.D., Charnes, A., and Cooper, W.W. ,1984, Some models for estimating technical and scale inefficiences in data envelop analysis, Management Science, 30, 1078-1092. 